Lalande for Venus and Mercury, showed with the observations very great errors which the theory of Laplace promised to eliminate, or at the very least to diminish. It was to the solution of these questions that Laplace directed the forces of the Bureau, and it was to their practical execution that he applied the resources which the budget granted him.

"To accelerate the work, the different parts were distributed to various members of the Bureau. The tables of the moon, on account of the constant use made of them in astronomy and navigation, were those which it was of special importance should be completed promptly; but the length of the researches, the magnitude of the calculations, which so complicated a theory required, only permitted the hope to be cherished that in the distant future errors might be made to disappear which had gone on increasing from day to day. This was the occasion of making an appeal to all astronomers, national and foreign, who might have sufficiently advanced works upon the lunar tables. With this object the Bureau des Longitudes was authorised to offer a prize."*

This prize of 8,000 francs was awarded by the Bureau to an astronomer of Vienna, Bürs, whose tables, based upon 2,500 observations, made at Greenwich from $i 765$ to I795, were deemed the most accurate and convenient. At the same time, Delambre published new tables of the sun; Bouvard, pupil of Laplace, whom he had assisted in the publication of the Mécanique céleste (Laplace resigned to him entirely the detailea investigations and astronomical calculations), published Nowvelles Tables des planetes Fupiter et Saturne (I808), a new edition of which he brought out in 1824 , to which were added tables of Herschel's planet, Uranus; Delambre published his Tables écliptiques des satellites de Fupiter (according to the theory of Laplace and the totality of the observations made from 1662 to 1802 ) ; Burckhardt, a German astronomer, whom the conquests of Napoleon had given to France, published new Tables de lo lune (1812), which, in the estimation of some astronomers, took the place of those of Bürg.

However, the impulse given by the splendid works of Laplace was not confined within the French frontiers. In Italy, a celebrated astronomer, Francisco Carline, published, in 1810 , new tables of the sun, which were soon employed everywhere except in France. 7 In Germany, a man of Science, who was at one and the same time an eminen lawyer, a distinguished captain, and an excellent astronomer, Bernhard von Lindenau, published, according to Laplace's theory, tables of Venus, Mars, and Mercury. *

Unfortunately these excellent woriks, due to the powerful initiative of Laplace, were not made use of in the publication of the Conmaissance des Temps.

In I 808 , Delambre, one of the most eminent French astronomers, indertook the direction of the Comaissance des Temps. No essential change was made in the work till 1817 ; at that time the right ascension of the moon, which had until then been calculated only to a minute, was given to a second for noon and midnight. Sailors could thus determine the longitude of their ships with more exactness; and astronomers, instead of finding in the Connaissance des Temps only the indication of the time at which they ought to observe our satellite, could thus compare the results of their observations with those which the tables gave, and prepare the material for their improvement. Finally, in 1820 , were introduced the diffe-

* Report of the Bureau des Longitudes, $x 800$.

$\dagger$ "Esposiz'one di un nuovo methodo di construire le Tavole Astromische applicato alle Tavole del Sole" (Milan, i810).

I "Tabula Veneris nova et correcta ex theoria gravitatis, clarissimi de Laplace, et ex observationibus recentissimis in specula astronomica Seebergensi habitis erecta" (Gotba, 1810). "Tabulae Martis nove et correctee cx theoria gravitatis, clarissinizi de Laplace, et ex observationibus recentissimis erecte" (Essenberg, r8xI). "Investigatio nova orbita a rnercurio circa soli descripta, accedumt Tabula Planetze ex Elementis recens repertis et theoria gravitatis, illustrissimi do Laplace consumctat "(Gotha, ISt3). rences in right ascension and in declination of the sun, differences useful in calculating the preceding co-ordinates at an hour other than that of noon. This was still another advantage to sailors.

But these improvements were of very little consequence in comparison with those which astronomy, geography, and navigation demanded. Germany was the first to set an example in this direction, and the Royal Astronomical Society of London, after a long and leamed discussion, came to the conclusion that they were necessary. Moreover, besides being incomplete, the Comnatsance dos Temps was full of errors from beginning to end, errata being found even among the errata themselves. Radical reforms were indispensable; but to make this clearly evident, we must return to the history of the "Nautical Almanac" and the Berlin "Jahrbuch."

(To be continued.)

\section{MAN IN THE SETTLE CAVE}

T NTIL the appearance of Mr. Tiddeman's paper in NATURE, vol. ix, p. r4, I had not fully realised the important issues which, according to him, depend upon the proper identification of the fragment of bone from the Victoria Cave to which he refers; nor was I aware that he was about to commit me in such very absolute terms to the opinion that it was human, but of this, as it tums out, I have no reason to complain.

Looking, however, at the apparent gravity of the statement, and knowing, also, that opinions might, and as believe did, differ as to the origin of the bone, I have been induced to go into the matter again, and am now in a position to affirm that there is no room for the slightest doubt on the subject.

Mr. James Flower, the excellent and estimable articinlator to the College of Surgeons, to whom I am under many obligations for assistance in such questions, and who at one time suggested, and had almost convinced me, that the bone was elephantine, has, after much search, found amongst the Museum stores of human osteology, a jibula which places the question beyond alt doubt, and fully confirms the opinion I had come to, especially after sceing the Mentone skeleton, that the Victoria relic, pre- or post-glacial as it may be, is human. It is further important as showing that bones of the same conformation may occasionally be met with at tille present day.

Harley Street, Nov. I4

GEO. BUSL

\section{NOTES}

DR. A. DEW-SMITte and Francis M. Balfour of Trinity College, Cambridge, have been nominated by the Buard of Natural Science Studies, in accordance with the grace of the Sernate (May I, I873), to study at the Zoological Station at Naples under Dr. Dohn, wintil the end of July I874.

At the General Mionthly Meeting of the Royal Institution to be held on Monday first, a President will be elected in the room. of the late Sir Henry Holland, Bart.

Professor Tr' QUAIR, of the Royal College of Science in Dublin, has been appointed to the Keepership of the Natural History Museum in the Edinburgh Museum of Science and Art. This gentleman was formerly one of the Demonstrators to the Professor of Biology in the University of Edinburgh, and is the author of several important contributions to Science.

MrR. W. F. BARRetT, F.C.S., has been appointed Proftssor of Physics to the Rroyal College of Science, Dublin, in succession to the late Professor W. Barker. We feel sure that this appoint- 